\title{
Comparison of different culture media for mycological evaluation of commercial pet food
}

\author{
Comparação de diferentes meios de cultura para a avaliação micológica de rações pet \\ Marina Venturini Copetti' ${ }^{1}$ Janio Morais Santurio ${ }^{2}$, Ayrton Sydnei Cavalheiro' ${ }^{2}$, \\ Sydney Hartz Alves ${ }^{2} \&$ Laerte Ferreiro $^{3}$
}

\begin{abstract}
The choice of a culture media to proceed a mycological analysis of food is extremely important to guarantee the reliability of the analysis. The medium should allow an excellent recovery of fungal species present in the food at the same time that it is necessary to avoid bacterial development. Thus the real microbial ecology will be reflected in the results. The efficacy of three media for fungal isolation and quantification (potato dextrose agar, dichloran rose of bengal and chloramphenicol agar and dichloran glycerol 18\% agar) was compared for analysis of 54 samples of dry commercial pet food (34 for dogs and 20 for cats). Fungi were present in $74 \%$ of samples and 23 genera were isolated and identified. Aspergillus sp. and Aspergillus niger were respectively the most frequent genera and species isolated, whatever the culture medium selected to proceed the analysis. Dichloran glycerol 18\% agar was the medium that presented the best results considering both the quantity and variety of isolated fungi. Comparing the results obtained in different media, it was observed that the fungi recovered can vary according to the selected culture medium. Eurotium was the genus that presented the biggest difference in occurrence among the media where samples were cultivated to enumeration in this study. Therefore, the utilization of specific media, selected according to the characteristics of the food to be analyzed (specially water activity) allow a better visualization of the presence of food spoilage fungi.
\end{abstract}

Keywords: mycobiota, pet food, Aspergillus sp., culture media, fungi, animal feed.

\section{RESUMO}

A seleção de um determinado meio de cultura para análise micológica de alimentos é de extrema importância para a garantia e segurança de uma análise, pois ao mesmo tempo que é desejável que este impeça o desenvolvimento de bactérias, ele deve permitir uma excelente recuperação das espécies fúngicas presentes no alimento, de modo que o resultado reflita a real ecologia microbiana no produto. Neste trabalho foi comparada a eficácia de três meios para isolamento e enumeração de fungos (ágar batata glicose, ágar dicloran rosa de bengala e cloranfenicol e ágar dicloran glicerol 18\%) a partir de 54 amostras de rações comerciais pet (34 para cães e 20 para gatos). Foi verificada a presença de fungos em $74 \%$ das amostras e 23 gêneros foram isolados e identificados. Aspergillus sp. e Aspergillus niger foram, respectivamente, o gênero e espécie mais frequentemente isolados, independentemente do meio de cultura utilizados para proceder a análise. O ágar dicloran glicerol 18\% foi o meio que apresentou os melhores resultados, quando considerados tanto a quantidade quanto a variedade de fungos isolados. Comparando os resultados obtidos nos diferentes meios, foi observado que os fungos isolados podem variar de acordo com o meio de cultura selecionado. O gênero Eurotium foi o que apresentou a maior diferença de ocorrência entre os meios avaliados para enumeração de fungos neste estudo. Portanto, a utilização de meios específicos, selecionados de acordo com as características do alimento a ser analisado (especialmente a atividade de água) permite uma melhor visualização da presença de fungos deterioradores de alimentos.

Descritores: micobiota, ração pet, Aspergillus sp., meio de cultura, fungos, ração animal. 


\section{INTRODUCTION}

A microbiological analysis of foods is carried out to guaran tee the quality and safety of the industrialized products. Enumeration of yeasts and filamentous fungi usually involves the inoculation of samples in solid culture media through surface or pour plate method [3]. In general, culture media for fungal evaluation need to be highly selective, suppressing the fast growing bacterial contamination [17] and limiting the growth rate and spread of fungal colonies [4], but should allow the enumeration of theoretically all species present in the samples. Unfortunately, there is not a single satisfactory method to detect or quantify yeasts and filamentous fungi in all food varieties.

Traditionally, potato dextrose agar has been used for a general quantification of fungi. However, this medium does not present an adequate nutritive source and can inhibit the recovering of damaged cells due to its low $\mathrm{pH}$ (3.5) [15]. More recently, media supplemented with antibiotics and dye, as the dichloran rose of bengal and chloramphenicol [10], emerged as a more efficient alternative. These media show a less toxic effect to the damaged cells, are more effective to inhibit the bacterial development and use to induce a smaller amount of food particles precipitation due its higher $\mathrm{pH}$ (5-6) [15]. Routinely, dichloran rose of bengal has been successfully applied to control the rate dissemination of fungal species, limiting the rapid spread of zygomycetes on the plate surface [10]. Later, media with reduced activity of water (Aw) were introduced, as the dichloran glycerol agar 18\% (Aw 0.95 ), for a general quantification of moderately xerophilic fungi, those with fastidious growth, which in a medium with traditional activity of water (Aw 0.99) may have their growth inhibited due to the rapid development of other species [9].

In this work, the efficacy of these three culture media for quantification and isolation of fungi from samples of commercial pet food was evaluated.

\section{MATERIALS AND METHODS}

\section{Samples}

Fifty-four packs of different dry pet food (34 for dogs and 20 for cats consumption), produced by nine different industries, were randomly purchased in supermarkets and rural shops in Santa Maria in January 2004. The samples were numerically identified and stored according to the pack instructions until analysis.

\section{Evaluation of fungal contamination of samples}

The samples were processed according to methodology by Samson et al. [15] for detection and isolation of fungi present in foods. All analyses were performed in triplicate under aseptic conditions.

Ten grams of each sample was re-hydrated in $90 \mathrm{~mL}$ of $0.1 \%$ peptone water solution for about one hour, homogenized and a ten-fold dilution was prepared.

Potato dextrose agar (PDA) ${ }^{1}$, dichloran rosebengal and chloramphenicol agar (DRBC) ${ }^{2}$ and dichloran glycerol 18\% agar (DG18) ${ }^{3}$ were used for fungal enumeration and identification in the genus level.

Samples were inoculated by surface or pour plate technique according to the dilution performed. For surface plating, $0.1 \mathrm{~mL}$ aliquots were inoculated in plates with solidified medium, spreading the inoculum on media surface. For the pour plating, $1 \mathrm{~mL}$ of the sample homogenized in peptone water was inoculated in the Petri dishes and $15-20 \mathrm{~mL}$ of culture medium at $45-50^{\circ} \mathrm{C}$ was added and mixed to the sample.

The plates were incubated at $28^{\circ} \mathrm{C}$ for $5-7$ days and examined for presence of yeasts and filamentous fungi. Plates presenting 10 to 100 colonies were selected for fungal enumeration and isolation. The results were expressed in colony forming unit per sample gram $(\mathrm{CFU} / \mathrm{g})$. Samples that resulted in cultures containing less than $10 \mathrm{CFU} / \mathrm{g}$ had the value found in the lowest tested dilution considered. All fungal species were first isolated onto Czapek Yeast extract agar (CYA) $)^{4}$ plates to future identification.

\section{Identification of Fungi}

The taxonomic identification of genus was followed, from the isolation media, according to the macro and microscopic characteristics of the colonies using adequate identification keys $[2,14,15]$.

Aspergillus sp. and Penicillium sp. isolates were grown on standard identification media, Czapek yeast extract agar (CYA) and malt extract agar (MEA) $)^{5}$. Penicillium sp. was identified according to Pitt \& Hocking [14], and Aspergillus sp. and Eurotium sp. identification was carried out following schemes of Pitt \& Hocking [14], Samson et al [15]. Fusarium sp. identification was carried out according to Nelson et al. key [13]. The other fungi were identified according to Pitt, \& Hocking [14] and Samson et al. [15].

Aspergillus sp. isolates were inoculated in 3 points in CYA and MEA plates and incubated for 7 days at $25^{\circ} \mathrm{C}$. The teleomorphic state Eurotium sp. was 
cultured in Czapek yeast extract $20 \%$ of sucrose agar (CY20S) during 14 days at $25^{\circ} \mathrm{C}$.

Penicillium sp. were also cultured following the above conditions and also in CYA at $5^{\circ} \mathrm{C}$ and $37^{\circ} \mathrm{C}$.

The colonies that after being subcultured during 21 days did not produce reproductive structures were considered as Mycelia sterilia [2].

The frequency $(\mathrm{F})$ of genus isolation (\%) was calculated as: $\mathrm{F}=$ (number of samples with genus presence/number of total samples) $\times 100$

\section{RESULTS}

The analysis permitted the classification of 23 genera, besides the detection of fungi identified only as Mycelia sterilia and yeasts in $40(74 \%)$ of the 54 samples of feeds (26 for dogs and 14 for cats). In 14 samples of feed ( 8 for dogs and 6 for cats) fungal presence was not detected.

The frequency of fungal isolation in the different media can be visualized in Figure 1.

Among the media evaluated, DG18 was the most efficacious medium to recover the fungal contamination in pet food. DG18 presented the better results both in the quantity as much as in the variety of fungi isolated from the evaluated pet food.

Comparatively, the medium PDA was the less efficacious and could not support the isolation of several genera, such as Cladosporium sp., Geotrichum sp., Monascus sp., Olyptrichum sp. and Phoma sp.

The genus Aspergillus was the most frequent fungi isolated in samples, independently of the culture medium used in the analysis. The Table 1 shows the frequency of occurrence of species of genus Aspergillus and its teleomorph Emericella and Eurotium.

The utilization of DG18 medium made possible the isolation of 18 Aspergillus species with a major occurrence of $A$. niger ( $40.7 \%$ of total samples). The species $A$. penicillioides and $E$. rubrum were fungi that only showed grow in DG18. PDA was the worse media tested if considered the fungal diversity isolated. In this medium were isolated only 14 distinct Aspergillus species, also with predominance of $A$. niger. The utilization of DRBC medium propitiate the isolation of 13 species, with major frequency of $A$. niger and $A$. candidus, both present in $18.5 \%$ of the pet food.

Out of 40 positive samples, $39(97,5 \%)$ presented contamination level ranged between $10^{1}$ and $10^{2} \mathrm{CFU} / \mathrm{g}$ (Table 2). Only one sample presented level of contamination of $10^{3} \mathrm{CFU} / \mathrm{g}$ with mycobiota dominated by yeasts.

\section{DISCUSSION}

Yeasts and filamentous fungi are extensively found in soil, water and air. Consequently, non-processed

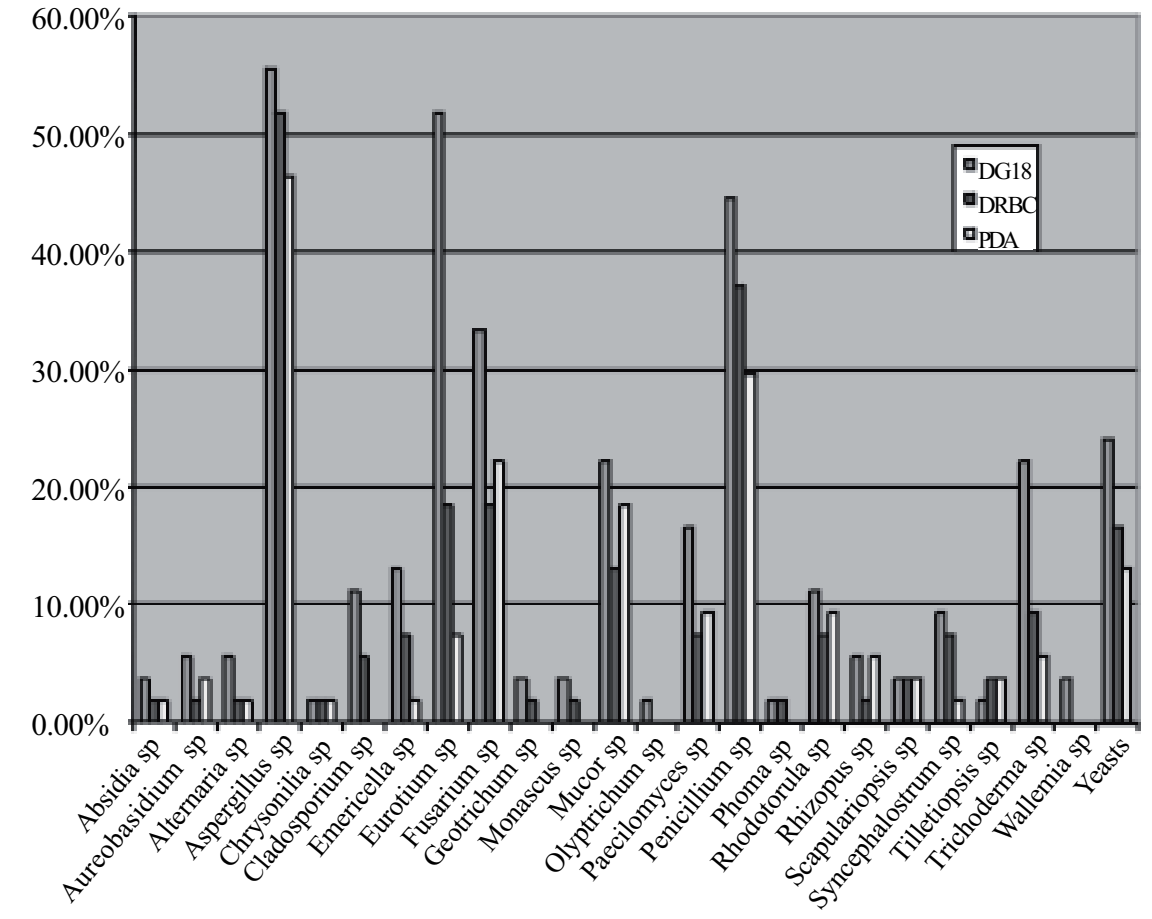

Figure 1. Frequency of fungal isolation from feeds for cats and dogs in different culture media. 
Table 1. Frequency of isolation of Aspergillus sp.and its teleomorphs from animal feeds using different culture media.

\begin{tabular}{|c|c|c|c|}
\hline & \multicolumn{3}{|c|}{ Number of samples with the species (Frequency \%) } \\
\hline & DG18 ${ }^{\mathrm{a}}$ & DRBC $^{\mathrm{b}}$ & PDA $^{c}$ \\
\hline Aspergillus and Teleomorphs & $37(68,52)$ & $31(57,41)$ & $29(53,65)$ \\
\hline Aspergillus niger & $22(40,74)$ & $10(18,52)$ & $16(29,6)$ \\
\hline A. candidus & $20(37,04)$ & $10(18,52)$ & $4(7,4)$ \\
\hline A. fumigatus & $11(20,37)$ & $5(9,27)$ & $6(11,12)$ \\
\hline A. flavus & $10(18,52)$ & $6(11,12)$ & $6(11,12)$ \\
\hline A. terreus & $9(16,67)$ & $6(11,12)$ & $6(11,12)$ \\
\hline A. versicolor & $7(12,96)$ & $5(9,27)$ & $1(1,85)$ \\
\hline A. sclerotiorum & $3(5,56)$ & 0 & $2(3,70)$ \\
\hline A. ochraceus & $3(5,56)$ & $1(1,85)$ & $1(1,85)$ \\
\hline A. oryzae & $2(3,70)$ & $1(1,85)$ & $2(3,70)$ \\
\hline A. penicillioides & $2(3,70)$ & 0 & 0 \\
\hline A. sydowii & $1(1,85)$ & 0 & $1(1,85)$ \\
\hline A. ustus & $1(1,85)$ & $1(1,85)$ & 0 \\
\hline A. wentii & $2(3,70)$ & 0 & $2(3,70)$ \\
\hline Emericella nidulans & $7(12,96)$ & $4(7,4)$ & $1(1,85)$ \\
\hline Eurotium amstelodami & $13(24,07)$ & $4(7,4)$ & $4(7,4)$ \\
\hline E. repens & $11(18,52)$ & $2(3,70)$ & $2(3,70)$ \\
\hline E. chevalieri & $3(5,56)$ & $2(3,70)$ & $2(3,70)$ \\
\hline E. rubrum & $1(1,85)$ & 0 & 0 \\
\hline
\end{tabular}

${ }^{a}$ DG18: Dichloran glycerol 18\% agar. ${ }^{b}$ DRBC: Dichloran rose-bengal and chloramphenicol agar. 'PDA: Potato dextrose agar.

Table 2. Average values and variation of total fungi counting (CFU/g) obtained by the different culture media in feeds for cats and dogs from different companies.

\begin{tabular}{|c|c|c|c|c|c|c|c|}
\hline \multirow{2}{*}{ Company } & \multirow{2}{*}{$\mathbf{n}^{\mathrm{d}}$} & \multicolumn{2}{|r|}{ DG18 $^{\mathrm{a}}$} & \multicolumn{2}{|c|}{ DRBC $^{\mathrm{b}}$} & \multicolumn{2}{|r|}{$\mathbf{P D A}^{\mathrm{c}}$} \\
\hline & & Average & Range & Average & Range & Average & Range \\
\hline 1 & 8 & 3,8 & $0-1,6 \times 10^{1}$ & 1,7 & $0-10^{1}$ & 2,1 & $0-10$ \\
\hline 2 & 19 & 9,4 & $0-1,2 \times 10^{2}$ & 5,5 & $0-5,3 \times 10^{1}$ & 6,2 & $0-4,3 \times 10$ \\
\hline 3 & 9 & 45,9 & $0-9 \times 10^{1}$ & 41,5 & $3-8 \times 10^{1}$ & 32,6 & $3-9 \times 10^{1}$ \\
\hline 4 & 3 & 315,6 & $10^{1}-4,8 \times 10^{2}$ & 275,6 & $410^{1}-4,5 \times 10^{2}$ & 222,2 & $6,3 \times 10^{1}-3,3 \times 10^{2}$ \\
\hline 5 & 7 & 97,6 & $10^{1}-4,6 \times 10^{2}$ & 106,7 & $210^{1}-4,9 \times 10^{2}$ & 86,7 & $0-4,6 \times 10^{2}$ \\
\hline 6 & 1 & 250,0 & $2,5 \times 10^{2}$ & 146,7 & $1,5 \times 10^{2}$ & 126,7 & $1,3 \times 10^{2}$ \\
\hline 7 & 2 & 156,7 & $2,3 \times 10^{1}-2,9 \times 10^{2}$ & 136,7 & $2,3 \times 10^{1}-2,5 \times 10^{2}$ & 136,7 & $3,3 \times 10^{1}-2,4 \times 10^{2}$ \\
\hline 8 & 4 & 1020,8 & $10^{1}-3,5 \times 10^{3}$ & 1011,7 & $1,3 \times 10^{1}-3,6 \times 10^{3}$ & 966,7 & $10^{1}-3,5 \times 103$ \\
\hline 9 & 1 & 330,0 & $3,3 \times 10^{2}$ & 203,3 & $2 \times 10^{2}$ & 63,3 & $6,3 \times 10^{1}$ \\
\hline Total & 54 & 133,9 & $0-3,5 \times 10^{3}$ & 124,7 & $0-3,6 \times 103$ & 111,7 & $0-3,5 \times 103$ \\
\hline
\end{tabular}

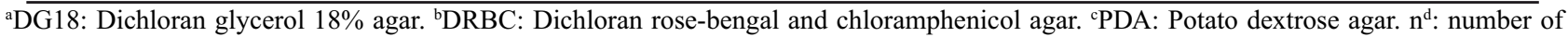
samples evaluated. 
materials of vegetal or animal origin are contaminated by them when they reach the industry. Good processing practices can originate products free of fungi or reduce its populations [18]. However, post processing contamination occurs. Giving enough time and growth conditions, surviving microorganisms can multiply and eventually deteriorate the product.

The detection and quantification of feasible cells of filamentous fungi and yeasts in processed products or not is a partial requirement of programs for quality control and can be utilized to monitor the efficacy of sanitary practices during the period of posharvesting of grains, slaughter of animals, processing and distribution of foods [3].

In a research performed by Scudamore et al. (1997), to evaluate the mycobiota present in pet foods utilizing malt agar and DG18, Aspergillus, Eurotium and Penicillium were found as predominant genera among 10 different isolated genera. These data is in accordance with the mycological results found in this study when analysis was carried out in DG18.

A great disparity in the number of Eurotium sp. recovered from the samples was observed among the media tested. Higher numbers of samples contaminated with Eurotium sp. were found in DG18 if compared with DRBC and PDA results. In similar study conducted by Martins et al. (2003) using DRBC, Aspergillus, Penicillium and Mucor were found as the most prevalent genera, while Aspergillus, Rhizopus and Mucor were reported by Bueno et al. [5] when the analysis was performed in PDA. The presence of Eurotium sp. was not reported in both studies. Eurotium sp. requires a minimum Aw for growth near 0.70. This genus is important in the spoilage of reduced Aw food, as the Aw found in commercial pet food. In culture media with a high Aw (0.99), as the DRBC and PDA, the Eurotium genus presents slow growth rate and can be surpassed by fast growing species, making difficult its recovering in culture. Thus, to mycological analyzes of low Aw food, the utilization of media with reduced Aw (0.95), such as DG18 [8], has been recommended by the International Commission in Food Mycology.

All the fungi reported in this research have already been isolated in foods. Those species that presented major frequency of occurrence belong to the group of moderately xerophilic fungi, which are capable to develop in Aw lower than 0.85, and are commonly associated with intermediate humidity foods, like animal feed [8].
The majority of xerotolerant fungi belong to the genera Aspergillus and Penicillium, or were the perfect state of Aspergillus, as the Eurotium and Emericella genera. When these microorganisms are present in food, they can spoil this product. One of the main factors to control the development of these microorganisms in food is the reduction of water available in the substrate, once the microbial deterioration is rare when the level of Aw are inferior to 0.65 [1].

Besides the action as important food spoilers, the majority of Aspergillus species and related teleomorphs isolated in this study are potentially producers of toxic metabolites. However, the minimum Aw required to synthesize toxins is superior to the minimum required to fungal multiplication [14].

A. niger, species potentially producer of ochratoxin A [7], was also the most frequent species isolated from feed in a study carried out in Portugal [12].

The isolation of $A$. penicillioides in food is rare and in this study it was only observed when samples were cultured in DC18. It has been attributed to the fact that this xerophilic species do not grow, or develop too slowly, in the media with high Aw commonly utilized for the isolation of fungi in food. Its growth is considered ideal in media with Aw 0.91-0.93 [14].

Fungal enumeration is an indicator of the quality of feed and should not exceed $10^{5} \mathrm{CFU} / \mathrm{g}$ in raw material for a feed with good microbiological quality [6]. The low levels of contamination in feed samples for cats and dogs have already been reported by other researchers $[12,16]$. These low levels probably are due to the high temperatures $\left(120^{\circ} \mathrm{C}\right)$ that ingredients are submitted to during extrusion, in the manufacturing process of the feed. The final mycobiota in the products are probably due to a recontamination of these in the processing environment, especially by the fungal spores present in the flour particles of cereals suspended in the air, and in a smaller proportion by a resistance to thermal treatment [18].

The control on fungal development during the storage of food is mainly reached through the low Aw in the final product [5]. The average values of Aw observed in the samples evaluated in this study was 0.61 , ranged between 0.465 and 0.820 (data not presented). Aw values found in most of the samples are under the minimum required to support fungal growth. However, the spores can remain viable for relatively long periods of time, and the storage of the feed in inadequate conditions, as in environments with 
high relative humidity and temperature, can propitiate favorable conditions to allow the fungal spores development and diverse toxins synthesis. The influence of relative humidity present of the environment in the fungal spoilage of pet food was demonstrated in a study carried out by Scudamore et al. [16].

The use of inhibitors, such as copper sulfate and organic acids, in the formulation of feed for cats and dogs can also contribute to inhibit the fungal development [11].

\section{CONCLUSION}

Considering the results verified in this study, it was observed that the mycobiota recovered from pet food can vary depending on media of cultivation selected. In this way, the use of a specific media, chosen according to the characteristics of each food is essential to a reliable evaluation of the presence of food spoilage fungi.

\section{INFORMATIVE NOTES}

${ }^{1}$ Potato Dextrose Agar (PDA), Laboratórios DIFCO, Diadema, SP/Brasil.

${ }^{2}$ Dichloran Rose-Bengal and Chloramphenicol agar (DRBC), Sigma Aldrich-Brasil Ltda., São Paulo, SP/Brasil. ${ }^{3}$ Dichloran Glycerol 18\% agar (DG18), Oxoid Brasil Ltda., São Paulo, SP/Brasil.

${ }^{4}$ Czapek Yeast extract Agar (CYA), Oxoid Brasil Ltda., São Paulo, SP/Brasil.

${ }^{5}$ Malt Extract Agar (MEA), Oxoid Brasil Ltda., São Paulo, SP/Brasil.

\section{REFERENCES}

1 Abellana M., Benedi J., Sanchos V. \& Ramos A.J. 1999. Water activity and temperature effects on germination of Eurotium amstelodami, E. chevalieri and E. herbariorum isolates from bakery products. Journal of Applied Microbiology. 87: 371-380.

2 Barnett H.L. \& Hunter B. 1998. Illustrated Genera of Imperfect Fungi. Saint Paul: The American Phytopathological Society.

3 Beuchat L.R. 1992. Media for detecting and enumerating yeasts and moulds. International Journal of Food Microbiology. 17: $145-158$.

4 Bragulat M.R., Abarca M.L., Castella G. \& Cabañes F.J. 1995. Dyes as fungal inhibitors: effects on colony enumeration. Journal of Applied Bacteriology. 79: 578-582.

5 Bueno D.J., Silva J.O. \& Oliver G. 2001. Mycoflora in commercial pet foods. Journal of Food Protection. 64 (5): 741-743.

6 Chelskowski J. 1991. Mycological quality o mixed feeds and ingredients. In: Chelskowski, J. (Ed). Cereal grain, Mycotoxins, Fungi and Quality in Drying and Storage. Amsterdam: Elsevier, pp. 217-227.

7 Dalcero, A., Magnoli, C., Hallak, C., Chiacchiera, S.M., Palacio, G., \& Rosas, C.A.R. 2002. Detection of ochratoxin A in animal feeds and capacity to produce this mycotoxins by Aspergillus section Nigri in Argentina. Food Additives and Contaminants. 19: 1065-1072.

8 Hocking A.D. \& Pitt J.I. 1987. Media and methods for detection and enumeration of microorganisms with consideration of water activity requirements. In: Rockland L.D. \& Beuchat L.R. (Eds.) Water Activity: Theory and applications to food. New York: Marcel Dekker Inc., pp.153-172.

9 Hocking A.D. \& Pitt J.L. 1980. Dichloran glycerol medium for enumeration of xerophilic fungi from low-moisture foods. Applied and Environmental Microbiology. 39: 488-492.

10 King A.D., Hocking A.D. \& Pitt J.l. 1979. Dichloran rose bengal medium for enumeration and isolation of molds from foods. Applied and Environmental Microbiology. 37: 959-964.

11 Maia P.P. \& Siqueira M.E.P.B. 2002. Occurrence of aflatoxins B1, B2, G1 and G2 in some Brazilians pet foods. Food Additives and Contaminants. 19 (12): 1180-1183.

12 Martins M.L., Martins H.M. \& Bernardo F. 2003. Fungal flora and mycotoxins detection in commercial pet food. Revista Portuguesa de Ciências Veterinárias. 98 (548): 179-183.

13 Nelson P.E., Toussoun T.A. \& Marasas W.F.O. 1983. Fusarium species: An illustrated manual for identification. The Pennsylvania State University Press, PA.

14 Pitt J.I. \& Hocking A.D. 1997. Fungi and food spoilage. Sydney: Division of Food Research.

15 Samson R.A., Hoekstra E.S., Frisvad J.C. \& Filtemborg O. 1996. Methods for the detection and isolation of food-borne fungi. In: Samson R.A., Hoekstra E.S., Frisvad J.C. \& Filtenborg O. (Eds). Introduction to food-borne fungi, The Netherlands: CBS, pp. 261-269. 
16 Scudamore K.A., Hetmanski M.T., Nawaz S., Naylor J. \& Rainbird S. 1997. Determination of mycotoxins in pet foods sold for domestic pets and wild birds using linked-column immunoassay clean-up and HPLC. Food Additives and Contaminants. 14 (2): 175-186.

17 Skaar I. \& Stewing H. 1996. Malt-Yest Extract- Sucrose Agar: A suitable medium to enumeration and isolation of fungi from silages. Applied and Environmental Microbiology. 62: 3614-3619.

18 Weidenbörner M., Wieczorek C., Appel S., \& Kunz B. 2000. Whole wheat and white wheat flour- the mycobiota and potential mycotoxins. Food Microbiology. 17: 103-107. 